\title{
Elżbieta Podział administracyjny Malinowska-Misiąg* a system finansowania gmin w Polsce
} Wojciech Misiąg**

Territorial division versus financing of municipalities in Poland

The aim of the paper is to assess the impact of the territorial division on the finances and activity of Polish local government units (LGUs). The basis for such an assessment was both an analysis of changes in the administrative division and an analysis of statistical data. The authors have drawn some conclusions concerning changes in the administrative system. The most important recommendation is to decrease the number of local government units, which would lead to reducing disparities in their financial capacity. Although the paper focuses mainly on the basic LGU (municipality), it also mentions the problem of powiats and voivodeships in the current shape.

\begin{tabular}{r|c}
\hline DOI & https://doi.org/10.31268/StudiaBAS.2021.33 \\
\hline Słowa kluczowe & reforma terytorialna, reorganizacje gmin, finansowanie gmin \\
\hline Keywords & territorial reform, municipal reorganisation, financing of municipalities \\
\hline 0 autorach & * doktor nauk ekonomicznych, adiunkt w Katedrze Systemu \\
& Finansowego SGH, Szkoła Główna Handlowa w Warszawie • \\
& ** emisia@sgh.waw.pl • ORCID 0000-0001-8710-781X \\
& doktor nauk ekonomicznych, profesor WSIiZ, dyrektor generalny \\
& Inftytutu Badań i Analiz Finansowych WSIiZ, Wyższa Szkoła i Zarządzania w Rzeszowie • \\
& $凶$ wmisiag@wiz.edu.pl • ORCID 0000-0002-1751-285X \\
\hline
\end{tabular}

Artykuł został udostępniony na licencji Creative Commons - Uznanie Autorstwa 3.0 Polska (CC BY 3.0 PL).

\section{Wprowadzenie}

Podział administracyjny państwa wyznaczający granice jednostek samorządu terytorialnego (JST) jest - obok ustrojowych zasad funkcjonowania JST i systemu ich finansów - jednym z podstawowych czynników kształtujących zdolność JST do efektywnego wykonywania ich zadań.

Łączenie JST jest uznawane za jeden ze sposobów zapewnienia im potencjału ekonomiczno-finansowego adekwatnego do zakresu świadczonych przez nie usług. Zwolennicy większych jednostek podkreślają przede wszystkim korzyści skali, przejawiające się m.in. w mniejszych kosztach wykonywania zadań publicznych, większych możliwościach absorpcji środków zewnętrznych (np. środków Unii Europejskiej), bardziej profesjonalnej administracji i relatywnie stabilnej bazie podatkowej. Inne argumenty są przedstawiane przez przeciwników łączenia JST - zwracają oni uwagę na brak korzyści skali (zwiększona produkcja wymaga większych nakładów), trudniejszy dostęp do administracji lokalnej, słabsze powiązania pomiędzy obywatelami i ich przedstawicielami'.

1 Por. P. Swianiewicz, A. Gendźwiłł, A. Zardi, Territorial Reforms in Europe: Does Size Matter? Territorial Amalgamation Toolkit, Centre of Expertise for Local Government Reform, Council of Europe, 2017, s. 20-22. 
W Europie reformy terytorialne i decentralizacyjne przeprowadzane od lat 50. ub. wieku miały na celu przede wszystkim zwiększenie efektywności świadczonych usług publicznych i wzmocnienie potencjału ekonomiczno-finansowego JST, a także umacnianie mechanizmów demokracji lokalnej. Niemniej jednak takie działania często prowadziły także do nasilania centralistycznych procesów zarządczych. Nierzadko tworzenie większych jednostek napotykało opór ze strony mieszkańców, co zmniejszało dynamikę tego procesu. Obecnie dodatkowym argumentem za łączeniem JST jest przeciwdziałanie niekorzystnym zmianom demograficznym².

W badaniach empirycznych z ostatnich lat poświęconych łączeniu się jednostek skupiono się na efektach ekonomicznych, zarządzaniu oraz wpływie na demokrację lokalną tego procesu. Mimo zróżnicowania pomiędzy państwami zauważalne są też pewne wspólne prawidłowości pojawiają się oszczędności związane głównie z wydatkami administracyjnymi, czasem poprawia się jakość świadczonych usług, jednocześnie jednak słabnie demokracja lokalna³.

W niniejszym artykule przedstawiono podstawowe problemy, jakie dla polskich JST wiążą się z podziałem administracyjnym państwa, podjęto też próbę oceny - na podstawie aktualnych danych statystycznych - wpływu tego podziału na finansowanie i skuteczność działań gmin na rzecz obywateli.

\section{Podział administracyjny Polski - rys historyczny}

Obecny podział administracyjny Polski jest w dużej mierze pochodną zmian wdrażanych po drugiej wojnie światowej. Po likwidacji samorządu terytorialnego w 1950 r. wprowadzono system rad narodowych, będących terenowymi organami jednolitej władzy państwowej w gminach, miastach i dzielnicach większych miast, w powiatach i województwach ${ }^{4}$. Wyodrębniono wówczas 2998 gmin, 704 miasta, 330 powiatów (w tym 59 miejskich) oraz 19 jednostek na poziomie wojewódzkim: 17 województw, miasto stołeczne Warszawę i miasto Łódź5

We wrześniu 1954 r. uchwalono ustawę likwidującą gminy i wprowadzającą nowe gromady ${ }^{6}$ jako jednostki podziału administracyjnego wsi ${ }^{7}$. Uznano, że gminy są zbyt duże, co utrudnia

2 S. Mazur, Modernizacja samorządu lokalnego w wybranych krajach - ujęcie modelowe [w:] Sprawne państwo. Reformy samorzqdu lokalnego w wybranych krajach, red. S. Mazur, Małopolska Szkoła Administracji Publicznej Uniwersytetu Ekonomicznego w Krakowie, Kraków 2015.

3 A.F. Tavares, Municipal Amalgamations and Their Effects: A Literature Review, „Miscellanea Geographica” 2018, t. 22, nr 1, https://doi.org/10.2478/mgrsd-2018-0005. Szerzej na temat reform terytorialnych w państwach europejskich np. w: Consolidation or Fragmentation? The Size of Local Governments in Central and Eastern Europe, red. P. Swianiewicz, Local Government and Public Service Reform Initiative, Open Society Institute, Budapest 2002; Territorial Consolidation Reforms in Europe, red. P. Swianiewicz, Local Government and Public Service Reform Initiative, Open Society Institute, Budapest 2010; J. Blom-Hansen, K. Houlberg, S. Serritzlew, D. Treisman, Jurisdiction Size and Local Government Policy Expenditure: Assessing the Effect of Municipal Amalgamation, „American Political Science Review” 2016, t. 110, nr 4, https://doi.org/10.1017/s0003055416000320.

4 Ustawa z dnia 20 marca 1950 r. o terenowych organach jednolitej władzy państwowej (Dz.U. nr 14, poz. 130).

5 Główny Urząd Statystyczny Rzeczypospolitej Polskiej, Rocznik statystyczny 1950, Warszawa 1951, s. 12 (stan na 6 lipca 1950 r.).

6 Gromady funkcjonowały też wcześniej - jako jednostki pomocnicze gmin.

7 Ustawa z dnia 25 września 1954 r. o reformie podziału administracyjnego wsi i powołaniu gromadzkich rad narodowych (Dz.U. nr 43, poz. 191). 
wykonywanie zadań publicznych. Nowe jednostki zmniejszono - miały obejmować wsie z terenu jednej gminy lub sąsiadujących ze sobą gmin, powiązane komunikacyjnie oraz posiadające wspólne urządzenia gospodarcze, kulturalne lub zdrowotne ${ }^{8}$. W efekcie system stał się mocno rozdrobniony - powstało 8790 gromad $^{9}$, lecz liczba ta zmniejszała się wraz z upływem lat. Podział na gromady obowiązywał do 1972 r., funkcjonowało ich wówczas 4315 . W 1973 r. zamiast zniesionych gromad ${ }^{10}$ ponownie pojawiły się gminy (2365 jednostek) ${ }^{11}$.

Kolejne zmiany nastąpiły w czerwcu 1975 r. Zlikwidowano wtedy powiaty i wprowadzono dwustopniowy podział administracyjny, w którym za jednostki stopnia podstawowego uznano gminy i miasta oraz dzielnice większych miast, natomiast jednostkami stopnia wojewódzkiego były województwa (49), miasto stołeczne Warszawa oraz miasta: Kraków, Łódź i Wrocław ${ }^{12}$.

Obecny podział administracyjny kraju został ukształtowany w wyniku dwóch reform. Pierwszą z nich wprowadzono na mocy ustawy z dnia 8 marca 1990 r. o samorządzie terytorialnym ${ }^{13}$. Miasta i gminy będące jednostkami stopnia podstawowego oraz miasto stołeczne Warszawa, miasto Kraków i miasto Łódź zachowały swoje nazwy, obszar, granice i siedziby władz. Gminom przekazano mienie należące do rad narodowych i terenowych organów administracji państwowej stopnia podstawowego, a także przedsiębiorstw pod ich nadzorem i innych jednostek organizacyjnych im podporządkowanych, natomiast Warszawie, Krakowowi i Łodzi - analogicznie mienie rad narodowych tych miast oraz terenowych organów administracji państwowej stopnia wojewódzkiego w tych województwach miejskich.

Gminom nadano osobowość prawną i zagwarantowano sądową ochronę niezależności. Stały się one podmiotami wykonującymi zadania publiczne we własnym imieniu i na własną odpowiedzialność. Do zakresu działalności gminy zaliczono wszystkie sprawy publiczne o znaczeniu lokalnym, niezastrzeżone ustawami na rzecz innych podmiotów. Na mocy ustawy lub zgodnie z porozumieniem z organami administracji rządowej gminom powierzono także zadania z zakresu tej administracji. Formalny podział zadań i kompetencji pomiędzy gminy i administrację rządową został dokonany na podstawie tzw. ustawy kompetencyjnej ${ }^{14}$. Problematyczne okazały się w szczególności zadania z zakresu oświaty i ochrony zdrowia oraz przesuwany termin obligatoryjnego przejmowania szkół, co spowodowało konieczność ponoszenia później przez gminy wysokich wydatków inwestycyjnych w placówkach nieremontowanych praktycznie od

8 Uchwała Rady Państwa i Rady Ministrów z dnia 24 lutego 1954 r. w sprawie prac przygotowawczych do powołania gromadzkich rad narodowych (M.P. $1954 \mathrm{nr} 22$, poz. 354).

9 Główny Urząd Statystyczny PRL, Rocznik statystyczny 1955, Warszawa 1956, s. 23 (stan na 30 września 1955 r.).

10 Ustawa z dnia 29 listopada 1972 r. o utworzeniu gmin i zmianie ustawy o radach narodowych (Dz.U. nr 49, poz. 312).

11 Główny Urząd Statystyczny, Rocznik statystyczny 1974, Warszawa 1974, s. 55 (stan na koniec 1973 r.).

12 Ustawa z dnia 28 maja 1975 r. o dwustopniowym podziale administracyjnym Państwa oraz o zmianie ustawy o radach narodowych (Dz.U. nr 16, poz. 91).

13 Dz.U. nr 16, poz. 95. Z dniem 29 grudnia 1998 r. tytuł ustawy został zmieniony na: ustawa z dnia 8 marca 1990 r. o samorządzie gminnym.

14 Ustawa z dnia 17 maja 1990 r. o podziale zadań i kompetencji określonych w ustawach szczególnych pomiędzy organy gminy a organy administracji rządowej oraz o zmianie niektórych ustaw (Dz.U. nr 34, poz. 198). 
1990 r. $^{15}$ Terenowe zadania rządowe wykonywali wojewodowie, liczba województw nie została zmieniona. W sierpniu 1990 r. utworzono sieć rejonów administracji ogólnej, które pełniły funkcje pomocnicze dla administracji rządowej na poziomie wojewódzkim. Status gminy jako podstawowej jednostki samorządu terytorialnego gwarantują przepisy konstytucyjne ${ }^{16}$.

Drugi etap reformy ustrojowej poprzedzało wiele dyskusji poświęconych przede wszystkim liczbie i obszarowi województw oraz wyborowi między dwustopniowym a trójstopniowym układem terytorialnym ${ }^{17}$. Finalnie zdecydowano o podziale trójstopniowym - w 1999 r. utworzono powiaty ${ }^{18}$ i województwa samorządowe ${ }^{19}$.

Punktem wyjścia do określenia nowego układu powiatowego stała się sieć urzędów rejonowych. Przyjęto przy tym, że powiaty powinny mieć co najmniej 50 tys. mieszkańców i obejmować co najmniej pięć gmin. W praktyce jednak założenia te nie zostały zrealizowane - w 1999 r. utworzono 50 powiatów z liczbą mieszkańców mniejszą niż 50 tys. (później liczba takich powiatów uległa jeszcze zwiększeniu), powstało także 11 powiatów składających się z mniej niż pięciu gmin ${ }^{20}$.

Zadania powiatu miały być zadaniami o charakterze ponadgminnym, m.in. z zakresu edukacji publicznej, promocji i ochrony zdrowia, pomocy społecznej, polityki prorodzinnej, transportu zbiorowego i dróg publicznych, geodezji, kartografii i katastru, administracji architektoniczno-budowlanej, porządku publicznego i bezpieczeństwa obywateli.

Samorząd województwa określa strategię rozwoju województwa i prowadzi politykę jego rozwoju. Do jego zadań należą te o charakterze wojewódzkim, np. z zakresu edukacji publicznej, promocji i ochrony zdrowia, kultury, zagospodarowania przestrzennego czy ochrony środowiska. Początkowo proponowano utworzenie 12 województw, liczba ta jednak została zwiększona najpierw o trzy, a finalnie o cztery (kujawsko-pomorskie, lubuskie, opolskie oraz świętokrzyskie). Obecnie liczba województw jest więc zbliżona do liczby województw (17) sprzed reformy z 1975 r.

Od czasu drugiego etapu reformy wprowadzono stosunkowo niewiele zmian w układzie terytorialnym państwa. Liczba województw pozostała niezmieniona, modyfikacje dotyczyły liczby gmin i powiatów. W 1999 r. funkcjonowało:

- 308 powiatów,

- 65 miast na prawach powiatu,

- 318 gmin miejskich ${ }^{21}$ (w tym 11 gmin m.st. Warszawy),

15 Szerzej: M. Mackiewicz, E. Malinowska, W. Misiąg, A. Niedzielski, M. Tomalak, Public Finance in Poland 19892001. Case Study of Transformation, Instytut Badań nad Gospodarką Rynkową, Warszawa 2002, s. 98.

16 Por. art. 164 ust. 1 Konstytucji Rzeczypospolitej Polskiej z dnia 2 kwietnia 1997 r. (Dz.U. nr 78, poz. 483, ze zm.). Analogiczny przepis był zawarty w tzw. małej konstytucji z 1992 r. - ustawie Konstytucyjnej z dnia 17 października 1992 r. o wzajemnych stosunkach między władzą ustawodawczą i wykonawczą Rzeczypospolitej Polskiej oraz o samorządzie terytorialnym (Dz.U. nr 84, poz. 426, ze zm.).

17 Szerzej np. w: A. Sekuła, Ewolucja instytucji samorzqdu terytorialnego w Polsce po roku 1989 [w:] Samorzqd terytorialny w krajach Unii Europejskiej, red. K. Gomółka, Państwowa Wyższa Szkoła Zawodowa, Elbląg 2007.

18 Ustawa z dnia 5 czerwca 1998 r. o samorządzie powiatowym (Dz.U. 2020, poz. 920, ze zm.).

19 Ustawa z dnia 5 czerwca 1998 r. o samorządzie województwa (Dz.U. 2020, poz. 1668, ze zm.).

20 Ministerstwo Administracji i Cyfryzacji, Ocena sytuacji samorzq̨dów lokalnych, Warszawa 2012, s. 19-20.

21 Zgodnie z rozporządzeniem Rady Ministrów z dnia 15 grudnia 1998 r. w sprawie szczegółowych zasad prowadzenia, stosowania i udostępniania krajowego rejestru urzędowego podziału terytorialnego kraju 
- 567 gmin miejsko-wiejskich,

- 1604 gminy wiejskie.

W ostatnich latach liczba powiatów wzrosła do 314, pojawiło się też kolejne miasto na prawach powiatu (Wałbrzych od 2013 r.). Zmieniono ustrój Warszawy - obecnie jest to jedna gmina o statusie miasta na prawach powiatu².

Według stanu na 1 stycznia 2021 r. w Polsce funkcjonują 302 gminy miejskie, 652 gminy miejsko-wiejskie i 1523 gminy wiejskie ${ }^{23}$. Zmiany dotyczyły wielkości terytorium niektórych jednostek; można tu w szczególności przytoczyć przykład Rzeszowa, którego powierzchnia

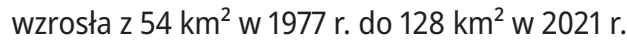

Warto podkreślić, że relatywnie stabilnemu ustawodawstwu ustrojowemu towarzyszyło w dużej mierze prowizoryczne i wielokrotnie modyfikowane ustawodawstwo finansowe, w tym rozwiązania, które trafiały finalnie do Trybunału Konstytucyjnego ${ }^{24}$.

\section{Problemy i wątpliwości}

Na mocy art. 7 ust. 1 ustawy z dnia 24 lipca 1998 r. o wprowadzeniu zasadniczego trójstopniowego podziału terytorialnego państwa ${ }^{25}$ Sejm, Senat i Rada Ministrów zostały zobligowane do dokonania oceny nowego podziału. W raporcie przyjętym przez Radę Ministrów w grudniu 2000 r. $^{26}$ za największą niedoskonałość reformy terytorialnej uznano utworzenie dużej liczby powiatów (46 jednostek) o niskim potencjale instytucjonalnym i funkcjonalnym, bez znaczących ośrodków miejskich. Zarówno Rada Ministrów, jak i Sejm oraz Senat uznały, że konieczne jest podjęcie pilnych kroków mających na celu łączenie się miast na prawach powiatu i powiatów z siedzibą swoich władz w tych miastach ${ }^{27}$. Działania takie zainicjowano - miasta na prawach powiatu i powiaty zostały poproszone o opinię na temat postulowanego połączenia. Ciąg dalszy był łatwy do przewidzenia - niemal połowa powiatów i wszystkie miasta na prawach powiatu wydały opinię negatywną ${ }^{28}$.

oraz związanych z tym obowiązków organów administracji rządowej i jednostek samorządu terytorialnego (Dz.U. nr 157, poz. 1031, ze zm.) gmina miejska to gmina o statusie miasta, gmina wiejska to gmina, na której terenie znajdują się wyłącznie wsie, natomiast gmina miejsko-wiejska oznacza gminę, na której terenie jedna z miejscowości ma status miasta, a pozostały teren jest obszarem wiejskim.

22 Por. ustawa z dnia 15 marca 2002 r. o ustroju miasta stołecznego Warszawy (Dz.U. 2018, poz. 1817).

23 https://eteryt.stat.gov.pl/eteryt/raporty/WebRaportZestawienie.aspx [dostęp: 20 października 2021 r.].

$24 \mathrm{H}$. Izdebski, Reformy samorzqdu terytorialnego oraz centrum administracyjnego i gospodarczego rzadu po 1989 roku [w:] Administracja państwowa i samorząd w Polsce w ujęciu historyczno-prawnym. Wybrane zagadnienia, red. E. Mreńca, P.B. Zientarski, B. Czwojdrak, Kancelaria Senatu, Warszawa 2018.

25 Dz.U. nr 96, poz. 603, ze zm.

26 Ocena nowego zasadniczego podziału terytorialnego państwa przyjęta przez Radę Ministrów w dniu 12 grudnia 2000 r., przygotowana przez Ministerstwo Spraw Wewnętrznych i Administracji, Warszawa 2000, s. 48.

27 https://archiwum.mswia.gov.pl/pl/aktualnosci/1644,Zasadniczy-trojstopniowy-podzial-terytorialny-panstwa-jest-fundamentem-dla-racjo.html [dostęp: 20 października 2021 r.]

28 Ministerstwo Administracji i Cyfryzacji, Ocena..., Warszawa 2012, s. 27. 
Niewątpliwie najsłabszym elementem obecnego układu terytorialnego są powiaty. Ścierają się głosy ich zwolenników, dla których powiaty to niezbędny szczebel pomiędzy szczeblem gminnym i wojewódzkim, oraz przeciwników, uznających powiaty za twór sztuczny i niepotrzebny. Obiektywnie można jednak stwierdzić, że powiaty to jednostki o wąskim zakresie działania i słabych podstawach finansowych ${ }^{29}$.

Wątpliwości dotyczą także województw. Jak zauważa H. Izdebski, obecny kształt i liczba województw są wynikiem przede wszystkim decyzji politycznych, nieuwzględniających kryterium wykonywania zadań regionalnych, i zasadna byłaby dyskusja nad powróceniem do koncepcji mniejszej liczby silniejszych regionów ${ }^{30}$.

Odrębną kwestią jest liczba gmin. Trudno liczyć na inicjatywy oddolne zmierzające do łączenia mniejszych jednostek. Takie przedsięwzięcia są podejmowane przede wszystkim w państwach o silnej kulturze współpracy i tradycji demokracji lokalnej oraz dużej autonomii finansów lokalnych ${ }^{31}$. W Polsce zachęty finansowe dla łączonych jednostek przewidziane w ustawie o dochodach JST okazują się niewystarczające ${ }^{32}$. Jak pisze P. Swianiewicz, reformy terytorialne należą do najtrudniejszych do przeprowadzenia - wzbudzają emocje dużej części mieszkańców i naruszają interesy polityczne ${ }^{33}$. Należy przy tym podkreślić, że nie można jednoznacznie określić optymalnej wielkości jednostki samorządu terytorialnego. Można jedynie stwierdzić, że wielkość taka powinna być adekwatna do rozwiązań modelowych przyjętych w poszczególnych państwach, w tym przede wszystkim do zakresu wykonywanych zadań, uwarunkowań finansowych i cech charakterystycznych dla danej jednostki, takich jak położenie czy demografia.

Jednostkami dysfunkcyjnymi w polskim układzie terytorialnym są tzw. jednostki obwarzankowe, czyli gminy wiejskie umiejscowione wokół gmin miejskich z siedzibą w gminie miejskiej oraz powiaty położone wokół miasta na prawach powiatu z siedzibą w tym mieście. W 2013 r. Ministerstwo Administracji i Cyfryzacji zidentyfikowało 158 gmin obwarzankowych (w tym 14 par z miastem na prawach powiatu) oraz 46 powiatów obwarzankowych. Jednostki obwarzankowe generują większe koszty administracyjne, utrudniają koordynację usług oraz nasilają efekt ,jazdy na gapę ${ }^{\prime \prime 34}$.

29 M. Mączyński, Czy istnieje potrzeba reformowania i różnicowania podstaw ustrojowo-organizacyjnych lokalnego samorzadu terytorialnego w Polsce? Argumenty za i przeciw w świetle ustawy o samorzadzie powiatowym [w:] Sprawne państwo. Systemowe zmiany w funkcjonowaniu polskiego samorządu terytorialnego, red. M. Ćwiklicki, Kraków 2015.

30 H. Izdebski, Trzeci etap reformy samorzadu terytorialnego de(re)centralizacja, postcovid i...?. Analiza Celowa nr 4/2021, Centrum Ekspertyzy Lokalnej, Fundacja Rozwoju Demokracji Lokalnej im. Jerzego Regulskiego.

31 J. Bober, J. Hausner, H. Izdebski, W. Lachiewicz, S. Mazur, A. Nelicki, B. Nowotarski, W. Puzyna, K. Surówka, I. Zachariasz, M. Zawicki, Narastajace dysfunkcje, zasadnicze dylematy, konieczne działania. Raport o stanie samorzq̨dności terytorialnej w Polsce, Małopolska Szkoła Administracji Publicznej Uniwersytetu Ekonomicznego w Krakowie, Kraków 2013, s. 23.

32 Zachęty te nie były wystarczające również po zmianach wprowadzonych w 2016 r. Por. art. 41 ustawy z dnia 13 listopada 2003 r. o dochodach jednostek samorządu terytorialnego (Dz.U. 2021, poz. 1672, ze zm.).

33 P. Swianiewicz, Ocena podziału terytorialnego państwa z uwzględnieniem efektywności funkcjonowania urzędów organów jednostek samorzqdu terytorialnego - wnioski i rekomendacje, Raport przygotowany na zlecenie Ministerstwa Administracji i Cyfryzacji, Warszawa 2014, s. 49.

34 Ministerstwo Administracji i Cyfryzacji, Polskie obwarzanki, Warszawa 2013 (prezentacja). 
Analiza aktów prawnych i politycznych deklaracji towarzyszących uchwalaniu ustaw konstytuujących podział administracyjny kraju oraz ustrój i organizację JST pozwala na wskazanie pewnych zasad, które - przynajmniej na poziomie deklarowanych intencji - powinny być podstawą delimitacji jednostek administracyjnych i główną przesłanką budowy systemu dochodów samorządowych. Za najważniejsze z tych zasad należy uznać:

- oparcie podziału administracyjnego na trójszczeblowym układzie JST, z gminami jako podstawowymi jednostkami podziału administracyjnego i samorządu terytorialnego,

- brak podległości jednostek „niższego” szczebla jednostkom „wyższego” szczebla,

- przyznanie jednakowych zadań i kompetencji wszystkim jednostkom zaliczanym do tego samego szczebla samorządu,

- możliwość nałożenia na JST obowiązku wykonywania zadań administracji rządowej, finansowanych z budżetu państwa,

- wdrożenie systemu dochodów JST zapewniających wszystkim obywatelom równy dostęp do usług publicznych świadczonych zgodnie z prawnie ustalonymi standardami.

W dalszej części artykułu zawarto próbę oceny, czy i w jakim stopniu istniejący podział administracyjny państwa sprzyja realizacji wyżej wymienionych postulatów ${ }^{35}$. Jest przy tym oczywiste, że podział administracyjny to tylko jeden z wielu czynników, od których zależy możliwość prawidłowego - a więc dobrze służącego mieszkańcom - wykonywania przez JST ich zadań. W artykule pominięto kwestie, skądinąd niezwykle ważne, sposobu podziału zadań publicznych pomiędzy administrację rządową i JST różnych szczebli czy zgodności systemu finansowego JST z podstawowymi zasadami samorządności. Skoncentrowano się natomiast na próbie ustalenia, czy przy obecnym zakresie zadań samorządowych system administracyjny spełnia postulat równego dostępu do dobrej jakości usług publicznych. Wymaga to nie tylko wyrównania potencjału dochodowego $\mathrm{JST}^{36}$, lecz także dostosowania go do zróżnicowanych kosztów wykonywania zadań. Co więcej, im bardziej zróżnicowane - co do charakteru i wielkości - są jednostki tego samego szczebla, tym trudniejsze jest osiągnięcie w miarę równomiernego rozkładu potencjału dochodowego.

\section{Zróżnicowanie JST}

Punktem wyjścia do analizy zróżnicowania jednostek samorządu terytorialnego są zawarte w tabeli 1 dane obrazujące rozpiętość podstawowych parametrów różnych szczebli systemu samorządu terytorialnego w $2020 \mathrm{r}$.

Uwagę zwraca przede wszystkim ogromne zróżnicowanie poziomu dochodów we wszystkich typach JST wyodrębnionych w tabeli 1. Okazuje się ono szczególnie duże wśród gmin wiejskich

35 Należy przy tym zauważyć, że z zasadami tymi sprzeczne jest zarówno utworzenie miast na prawach powiatu rozszerzające zakres zadań i kompetencji niektórych gmin, jak i przyznanie zarządom województw samorządowych funkcji instytucji zarządzających regionalnymi programami operacyjnymi, co w oczywisty sposób tworzy pewien stosunek podległości gmin i powiatów wobec samorządu województwa.

36 O różnych klasyfikacjach potencjału szerzej w: E. Malinowska-Misiąg, Potencjał dochodowy jednostek samorządu terytorialnego w Polsce, Oficyna Wydawnicza SGH, Warszawa 2019. 
i nie jest to bynajmniej wyłącznie efekt zaliczania do gmin wiejskich Kleszczowa, którego dochody na jednego mieszkańca zdecydowanie przewyższają dochody wszystkich pozostałych gmin. Ważniejsze jest to, że poziom dochodów w najbiedniejszych gminach wiejskich (a także w najbiedniejszych gminach miejsko-wiejskich) jest równy zaledwie 65-70\% średnich dochodów na jednego mieszkańca wszystkich polskich gmin.

Zamieszczenie w tabeli 1 kolumn opisujących zróżnicowanie powiatów i województw przez zsumowanie dochodów wszystkich JST z terenów tych jednostek pozwala na rzetelne porównanie potencjału dochodowego miast na prawach powiatu i powiatów ziemskich, gdyż dopiero po zagregowaniu dochodów samorządu powiatu i gmin wchodzących w skład tego powiatu otrzymujemy dane porównywalne co do rodzajów dochodów i wykonywanych zadań z danymi odnoszącymi się do miast na prawach powiatu. Takie ujęcie umożliwia także wykazanie, że regionalne zróżnicowanie dochodów jest znaczne, chociaż oczywiście mniejsze niż w przypadku $\operatorname{gmin}^{37}$.

Tabela 1. Zróżnicowanie jednostek samorządu terytorialnego w 2020 r.

\begin{tabular}{|c|c|c|c|c|c|c|}
\hline & \multicolumn{4}{|c|}{ Gminy } & \multirow[b]{2}{*}{ Powiaty* } & \multirow[b]{2}{*}{$\begin{array}{l}\text { Woje- } \\
\text { wódz- } \\
\text { twa** }\end{array}$} \\
\hline & Miejskie & $\begin{array}{l}\text { Miasta na } \\
\text { prawach } \\
\text { powiatu }\end{array}$ & $\begin{array}{l}\text { Miejsko- } \\
\text {-wiejskie }\end{array}$ & Wiejskie & & \\
\hline \multicolumn{7}{|c|}{ Powierzchnia $\left(\mathrm{w} \mathrm{km}^{2}\right)$} \\
\hline minimum & 10,98 & 10,19 & 3,74 & 3,32 & 158,15 & 9411,87 \\
\hline maksimum & 633,7 & 430,09 & 498,87 & 574,91 & 2976,44 & 35558,47 \\
\hline \multicolumn{7}{|c|}{ Liczba mieszkańców } \\
\hline minimum & 1279 & 35562 & 1626 & 1470 & 19807 & 980771 \\
\hline maksimum & 72949 & 1793579 & 85730 & 34471 & 403417 & 5428031 \\
\hline \multicolumn{7}{|c|}{ Gęstość zaludnienia (os./km²) } \\
\hline minimum & 10,79 & 202,23 & 8,22 & 4,33 & 18,94 & 58,28 \\
\hline maksimum & 3974,08 & 3708,72 & 840,97 & 576,00 & 675,75 & 365,53 \\
\hline \multicolumn{7}{|c|}{ Dochody JST na osobę (w zł) } \\
\hline minimum & 4369,52 & 6112,78 & 4192,19 & 3993,71 & 5740,55 & 7426,88 \\
\hline maksimum & 12457,10 & 14753,11 & 11697,74 & 41002,45 & 9541,88 & 9124,98 \\
\hline \multicolumn{7}{|c|}{$\begin{array}{l}\text { * dochody wszystkich JST z terenu powiatu } \\
\text { ** dochody wszystkich JST z terenu województwa } \\
\text { Źródło: obliczenia własne na podstawie danych Ministerstwa Finansów, https://www.gov.pl/web/finanse/bazy- } \\
\text {-danych3 [dostęp: } 10 \text { września } 2021 \text { r.] i danych Głównego Urzędu Statystycznego, https://bdl.stat.gov.pl/BDL/ } \\
\text { [dostęp: } 10 \text { września } 2021 \text { r.]. }\end{array}$} \\
\hline
\end{tabular}

37 Dodać należy, że wielkości dochodów na osobę w powiatach i województwach (w przyjętym tutaj ujęciu) pokazują kwotę wszystkich dochodów samorządowych przypadających na jednego mieszkańca - wydaje się to znacznie ważniejsze od prezentowania dochodów samorządów powiatowych i wojewódzkich. 
Dla dalszych rozważań istotne jest również to, że najwyższe dochody osiągają te gminy wiejskie, których zasadnicze funkcje i główne źródła dochodów leżą poza rolnictwem - są to m.in. gminy turystyczne (Rewal, Ustronie Morskie, Sękowa, Solina), gminy stanowiące zaplecze dużych miast (Jerzmanowa, Suchy Las, Kobierzyce), a także gminy czerpiące znaczne dochody z działających na ich terenie kopalni odkrywkowych (Kleszczów, Rząśnia). Dobrze ilustruje to tabela 2, w której przedstawiono 10 gmin wiejskich charakteryzujących się w 2020 r. najwyższymi dochodami na osobę i 10 gmin z najniższymi dochodami. Należy zauważyć, że gminy o najniższych dochodach odznaczają się znacznie niższą średnią liczbą mieszkańców.

Tabela 2. Gminy wiejskie o najwyższych i najniższych dochodach na mieszkańca w 2020 r.

\begin{tabular}{|c|c|c|c|c|}
\hline Gmina & Województwo & Ludność & $\begin{array}{l}\text { Dochody } \\
\text { (w mln zf) }\end{array}$ & $\begin{array}{l}\text { Dochody na miesz- } \\
\text { kańca (w zł) }\end{array}$ \\
\hline Kleszczów & Łódzkie & 6370 & 261,2 & 41002,4 \\
\hline Rewal & Zachodniopomorskie & 3871 & 50,8 & 13110,6 \\
\hline Kobierzyce & Dolnośląskie & 22024 & 285,5 & 12963,7 \\
\hline Solina & Podkarpackie & 5320 & 66,1 & 12417,7 \\
\hline Jerzmanowa & Dolnośląskie & 5269 & 62,5 & 11854,2 \\
\hline Rząśnia & Łódzkie & 4935 & 55,5 & 11250,5 \\
\hline Sulmierzyce & Łódzkie & 4437 & 48,2 & 10857,7 \\
\hline Suchy Las & Wielkopolskie & 18407 & 196,6 & 10678,2 \\
\hline Ustronie Morskie & Zachodniopomorskie & 3671 & 39,0 & 10637,2 \\
\hline Sękowa & Małopolskie & 4967 & 52,5 & 10565,9 \\
\hline \multicolumn{5}{|l|}{$\ldots$} \\
\hline Bytnica & Lubuskie & 2491 & 11,2 & 4510,4 \\
\hline Izbicko & Opolskie & 5401 & 24,1 & 4459,9 \\
\hline Nędza & Śląskie & 7462 & 33,2 & 4445,9 \\
\hline Grodzisk & Podlaskie & 4140 & 18,4 & 4432,6 \\
\hline Uchanie & Lubelskie & 4502 & 19,9 & 4425,3 \\
\hline Bliżyn & Świętokrzyskie & 8016 & 34,8 & 4341,3 \\
\hline Bolesław & Małopolskie & 2598 & 11,2 & 4310,3 \\
\hline Gorzków & Lubelskie & 3416 & 14,7 & 4292,9 \\
\hline Tarłów & Świętokrzyskie & 5110 & 21,6 & 4236,5 \\
\hline Wietrzychowice & Małopolskie & 3942 & 15,7 & 3993,7 \\
\hline
\end{tabular}

Źródło: obliczenia własne na podstawie danych Ministerstwa Finansów, https://www.gov.pl/web/finanse/bazy-danych3 [dostęp: 10 września 2021 r.].

Przeważającą część populacji gmin wiejskich stanowią gminy małe, a nawet bardzo małe. Jak widać w tabeli 3, więcej niż jedna trzecia gmin wiejskich ma mniej niż 5 tys. mieszkańców, a tylko w $18 \%$ tych gmin liczba mieszkańców przekracza 10 tys. Dalej pokazano, że funkcjonowanie dużej liczby małych gmin wiejskich ma istotny wpływ na ich potencjał dochodowy. Przeanali- 
Tabela 3. Gminy według rodzajów i klas liczby ludności

\begin{tabular}{|c|c|c|c|c|c|c|}
\hline \multirow{3}{*}{$\begin{array}{c}\text { Klasy liczby } \\
\text { ludności } \\
\text { (w tys.) }\end{array}$} & \multicolumn{6}{|c|}{ Gminy } \\
\hline & \multicolumn{2}{|c|}{ Ogółem } & \multirow{2}{*}{$\begin{array}{c}\text { Miejskie } \\
\text { bez miast } \\
\text { na prawach } \\
\text { powiatu }\end{array}$} & \multirow{2}{*}{$\begin{array}{c}\text { Miasta } \\
\text { na prawach } \\
\text { powiatu }\end{array}$} & \multirow{2}{*}{$\begin{array}{l}\text { Miejsko- } \\
\text {-wiejskie }\end{array}$} & \multirow[t]{2}{*}{ Wiejskie } \\
\hline & liczba & $(w \%)$ & & & & \\
\hline Ogółem & 2477 & 100,00 & 236 & 66 & 642 & 1533 \\
\hline $0-3$ & 119 & 4,80 & 7 & - & 5 & 107 \\
\hline $3-5$ & 527 & 21,28 & 16 & - & 39 & 472 \\
\hline $5-10$ & 943 & 38,07 & 25 & - & 241 & 677 \\
\hline $10-15$ & 362 & 14,61 & 28 & - & 140 & 194 \\
\hline $15-20$ & 181 & 7,31 & 40 & - & 89 & 52 \\
\hline $20-25$ & 98 & 3,96 & 26 & - & 56 & 16 \\
\hline $25-30$ & 57 & 2,30 & 18 & - & 27 & 12 \\
\hline $30-35$ & 38 & 1,53 & 16 & - & 19 & 3 \\
\hline $35-40$ & 26 & 1,05 & 19 & 1 & 6 & - \\
\hline $40-60$ & 51 & 2,06 & 25 & 8 & 18 & - \\
\hline $60-80$ & 30 & 1,21 & 16 & 13 & 1 & - \\
\hline $80-100$ & 8 & 0,32 & - & 7 & 1 & - \\
\hline $100-200$ & 22 & 0,89 & - & 22 & - & - \\
\hline $200-300$ & 6 & 0,24 & - & 6 & - & - \\
\hline $300-500$ & 4 & 0,16 & - & 4 & - & - \\
\hline 500-1000 & 4 & 0,16 & - & 4 & - & - \\
\hline Ponad 1000 & 1 & 0,04 & - & 1 & - & - \\
\hline
\end{tabular}

Źródło: obliczenia własne na podstawie danych Ministerstwa Finansów, https://www.gov.pl/web/finanse/bazy-danych3 [dostęp: 10 września 2021 r.].

zowano także - w podziale na rodzaje gmin i liczbę ich mieszkańców - dane o przypadających na jednego mieszkańca dochodach przeznaczonych na finansowanie zadań własnych ${ }^{38}$. Wyszczególniono - tak jak poprzednio - cztery grupy gmin i 17 klas ich wielkości mierzonej liczbą mieszkańców. Warto przypomnieć, że gminy o liczbie ludności mniejszej od 10 tys. stanowiły w 2020 r. ponad 64\% ogólnej liczby gmin. Ciemniejszym kolorem tła wyróżniono w tabeli 4 te grupy gmin, dla których przeciętne dochody na mieszkańca są niższe od średniej krajowej. Przy dokonywaniu analizy danych należy pamiętać, że dochody miast na prawach powiatu obejmują również dochody związane z wykonywaniem zadań własnych powiatów, które w 2020 r. wynosiły średnio ok. 1275 zł na osobę.

38 Za dochody służące finansowaniu zadań własnych uznano wszystkie dochody JST poza dotacjami z budżetu państwa na zadania zlecone JST na mocy ustaw. 
Tabela 4. Dochody per capita gmin na zadania własne według rodzajów gmin i liczby mieszkańców

\begin{tabular}{|c|c|c|c|c|c|c|}
\hline \multirow{3}{*}{$\begin{array}{l}\text { Klasy liczby ludności } \\
\text { (w tys.) }\end{array}$} & \multicolumn{6}{|c|}{ Gminy } \\
\hline & \multicolumn{2}{|c|}{ Ogółem } & \multirow{2}{*}{$\begin{array}{l}\text { Miejskie } \\
\text { bez } \\
\text { miast na } \\
\text { prawach } \\
\text { powiatu }\end{array}$} & \multirow{2}{*}{\multicolumn{2}{|c|}{\begin{tabular}{c|c}
$\begin{array}{c}\text { Miasta na } \\
\text { prawach } \\
\text { powiatu }\end{array}$ & $\begin{array}{l}\text { Miejsko- } \\
\text {-wiejskie }\end{array}$ \\
(w zl)
\end{tabular}}} & \multirow[t]{2}{*}{ Wiejskie } \\
\hline & $\left(w z-z^{\prime}\right)$ & $\begin{array}{c}\text { Polska }= \\
100\end{array}$ & & & & \\
\hline Ogółem & 4949,01 & 100,00 & 4101,37 & 6528,05 & 4098,09 & 4290,93 \\
\hline $0-3$ & 4424,70 & 89,41 & 5602,52 & - & 4059,52 & 4369,25 \\
\hline $3-5$ & 4277,09 & 86,42 & 5860,18 & - & 4586,98 & 4196,38 \\
\hline $5-10$ & 4223,10 & 85,33 & 4646,12 & - & 4150,75 & 4234,54 \\
\hline $10-15$ & 4063,91 & 82,12 & 4024,80 & - & 3953,30 & 4151,73 \\
\hline $15-20$ & 4178,50 & 84,43 & 4109,13 & - & 3948,74 & 4626,68 \\
\hline $20-25$ & 4168,22 & 84,22 & 4102,67 & - & 4008,32 & 4838,45 \\
\hline $25-30$ & 4440,57 & 89,73 & 4022,00 & - & 4532,49 & 4864,75 \\
\hline $30-35$ & 4045,08 & 81,74 & 3986,43 & - & 3947,24 & 4973,71 \\
\hline $35-40$ & 4301,43 & 86,92 & 4140,90 & 9411,96 & 4000,58 & - \\
\hline $40-60$ & 4472,54 & 90,37 & 4025,76 & 6510,15 & 4157,44 & - \\
\hline $60-80$ & 4837,74 & 97,75 & 4049,89 & 5779,18 & 4728,85 & - \\
\hline $80-100$ & 5583,49 & 112,82 & - & 5590,96 & 5527,16 & - \\
\hline $100-200$ & 6035,48 & 121,95 & - & 6035,48 & - & - \\
\hline $200-300$ & 5972,28 & 120,68 & - & 5972,28 & - & - \\
\hline $300-500$ & 6114,34 & 123,55 & - & 6114,34 & - & - \\
\hline 500-1000 & 6483,44 & 131,00 & - & 6483,44 & - & - \\
\hline Ponad 1000 & 8925,14 & 180,34 & - & 8925,14 & - & - \\
\hline $\begin{array}{l}\text { Odsetek gmin z dochodami } \\
\text { na osobę powyżej średniej } \\
\text { krajowej }\end{array}$ & 13,2 & & 11,4 & 87,9 & 10,4 & 11,5 \\
\hline
\end{tabular}

Źródło: obliczenia własne na podstawie danych Ministerstwa Finansów, https://www.gov.pl/web/finanse/bazy-danych3 [dostęp: 10 września 2021 r.].

Na podstawie danych z tabeli 4 można sformułować kilka wniosków potwierdzających tezę o niekorzystnym wpływie dużego rozdrobnienia w wyniku podziału administracyjnego i pozwalających na korektę pewnych obiegowych sądów dotyczących rozkładu dochodów JST.

- Rozkład dochodów gmin jest skrajnie asymetryczny. Średnie dochody na mieszkańca w wyróżnionych grupach gmin są niższe od średniej krajowej w prawie wszystkich grupach gmin poza miastami na prawach powiatu. Łączna liczba gmin zaliczanych do grup, w których średnie dochody są niższe od średniej krajowej, stanowi ok. 94,5\% liczby wszystkich gmin, 
chociaż w grupach tych mogą występować gminy z dochodami przewyższającymi średnią krajową.

- Nie ma widocznej różnicy w sytuacji dochodowej gmin wiejskich i miejsko-wiejskich. Co więcej, w większości wyróżnionych klas liczby mieszkańców średnie dochody gmin wiejskich są wyższe niż w identycznych co do liczby mieszkańców gminach miejsko-wiejskich. Oznacza to, że będące na terenie gminy niewielkie miasto nie zapewnia jej wyższych dochodów na mieszkańca.

- W grupie gmin wiejskich wyraźny jest związek średniego poziomu dochodów na jednego mieszkańca z liczbą mieszkańców. Związku takiego nie widać natomiast w innych rodzajach gmin.

- Wysokie dochody na jednego mieszkańca małych miast i małych miast na prawach powiatu nie mają istotnego znaczenia dla całego rozkładu dochodów - wynika to z bardzo małej liczebności tych grup gmin. Spektakularnym przykładem jest rozkład dochodów miast na prawach powiatu - najwyższe dochody (ponad 9400 zł) odnotowano w 2020 r. w Sopocie, będącym jedynym miastem na prawach powiatu o liczbie mieszkańców mniejszej od 40 tys. Niski poziom dochodów najmniejszych gmin musi mieć swoje konsekwencje w postaci problemów z właściwym finansowaniem zadań samorządowych. Problemy te zilustrowano zestawieniami wydatków (przeliczonych na jednego mieszkańca) na oświatę i wychowanie ${ }^{39}$ oraz na administrację. Wydatki na oświatę absorbują największą część dochodów gmin, natomiast przykład administracji jest interesujący z tego względu, że wydatki na administrację gminną przypadające na jednego mieszkańca są bardzo silnie skorelowane z liczbą mieszkańców gminy.

W prawie wszystkich gminach wiejskich wydatki oświatowe gmin wiejskich (także wydatki przeważającej większości mniejszych gmin miejskich i miejsko-wiejskich) na jednego ucznia są wyraźnie niższe od średniej krajowej ${ }^{40}$. Niepokój spowodowany niskim poziomem wydatków oświatowych w gminach wiejskich jest tym większy, że można wskazać co najmniej kilka ważnych przyczyn, dla których obiektywnie niezbędny poziom wydatków oświatowych w małych gminach powinien być wyższy niż w większych ośrodkach miejskich. Wymienić tu należy w szczególności:

- przeciętnie mniejszą liczbę uczniów na jedną szkołę i jeden oddział szkolny (klasę),

- większy niż w dużych gminach odsetek szkół położonych w małych miejscowościach i związany z tym większy odsetek nauczycieli, którym przysługuje dodatek za pracę w takich miejscowościach,

- gorszy stan techniczny budynków szkolnych spowodowany brakiem wystarczających środków na inwestycje będących do dyspozycji mniejszych gmin,

- niższe (przeciętnie) wykształcenie rodziców i związany z tym mniejszy zasób wiedzy wynoszonej przez uczniów z domów rodzinnych ${ }^{41}$.

39 Wydatki te są rozumiane jako wydatki klasyfikowane w dziale 801 - „Oświata i wychowanie”.

40 Wyjątek stanowi 15 największych gmin wiejskich, w których wydatki oświatowe przekraczają średnią krajową.

41 Taką tezę potwierdzają m.in. badania, których wyniki zawarto w: Edukacja małych dzieci. Standardy, bariery, szanse, red. A. Giza, Fundacja Rozwoju Dzieci im. Jana Amosa Komeńskiego, Polsko-Amerykańska Fundacja Wolności, Warszawa 2010; Uwarunkowania decyzji edukacyjnych. Wyniki pierwszej rundy badania panelowego gospodarstw domowych, red. M. Rószczyńska, K. Saczek, Instytut Badań Edukacyjnych, Warszawa 2014; 
Tabela 5. Wydatki gmin (na jednego mieszkańca w wieku szkolnym*) na oświatę według rodzajów gmin i klas liczby ludności

\begin{tabular}{|c|c|c|c|c|c|c|}
\hline \multirow{3}{*}{$\begin{array}{c}\text { Klasy liczby } \\
\text { ludności } \\
\text { (w tys.) }\end{array}$} & \multicolumn{6}{|c|}{ Gminy } \\
\hline & \multicolumn{2}{|c|}{ Ogółem } & \multirow{2}{*}{$\begin{array}{c}\text { Miejskie } \\
\text { bez miast } \\
\text { na prawach } \\
\text { powiatu }\end{array}$} & \multirow{2}{*}{$\begin{array}{c}\text { Miasta } \\
\text { na prawach } \\
\text { powiatu }\end{array}$} & \multirow[t]{2}{*}{$\begin{array}{l}\text { Miejsko- } \\
\text {-wiejskie }\end{array}$} & \multirow[t]{2}{*}{ Wiejskie } \\
\hline & $(w z-)$ & Polska $=100$ & & & & \\
\hline Ogółem & 19117,53 & 100,00 & 18853,49 & 20688,07 & 17996,25 & 17975,28 \\
\hline $0-3$ & 17738,12 & 92,78 & 20285,24 & - & 17708,51 & 17580,28 \\
\hline $3-5$ & 17729,58 & 92,74 & 22972,53 & - & 17880,50 & 17557,72 \\
\hline $5-10$ & 17975,92 & 94,03 & 18436,75 & - & 17946,67 & 17970,86 \\
\hline $10-15$ & 17806,11 & 93,14 & 18417,33 & - & 18126,32 & 17516,53 \\
\hline $15-20$ & 18034,85 & 94,34 & 19647,73 & - & 17064,27 & 18455,56 \\
\hline $20-25$ & 18259,25 & 95,51 & 19132,74 & - & 17952,11 & 18025,66 \\
\hline $25-30$ & 19135,28 & 100,09 & 18318,31 & - & 18952,64 & 20384,84 \\
\hline $30-35$ & 18363,00 & 96,05 & 18616,05 & - & 17366,97 & 22332,30 \\
\hline $35-40$ & 19361,18 & 101,27 & 18851,69 & 29705,22 & 19367,51 & - \\
\hline $40-60$ & 18627,27 & 97,44 & 18333,49 & 19771,21 & 18320,06 & - \\
\hline $60-80$ & 20504,73 & 107,26 & 19090,75 & 21704,30 & 19449,33 & - \\
\hline $80-100$ & 20120,61 & 105,25 & - & 19968,75 & 21317,51 & - \\
\hline $100-200$ & 19881,60 & 104,00 & - & 19881,60 & - & - \\
\hline $200-300$ & 20666,11 & 108,10 & - & 20666,11 & - & - \\
\hline $300-500$ & 19684,73 & 102,97 & - & 19684,73 & - & - \\
\hline 500-1000 & 20759,07 & 108,59 & - & 20759,07 & - & - \\
\hline Ponad 1000 & 22648,90 & 118,47 & - & 22648,90 & - & - \\
\hline
\end{tabular}

* dla miast na prawach powiatu - od 7 do 18 lat, dla pozostałych gmin - od 7 do 14 lat Źródło: obliczenia własne na podstawie danych Ministerstwa Finansów, https://www.gov.pl/web/finanse/bazy-danych [dostęp: 10 września 2021 r.].

Gdy uwzględni się te czynniki, należy uznać, że poziom wydatków oświatowych w małych gminach jest uwarunkowany głównie niedostatecznymi zasobami środków finansowych i w efekcie - niepełnym zaspokojeniem realnych potrzeb finansowych szkół. Znajduje to potwierdzenie w wynikach nauczania - według danych Centralnej Komisji Egzaminacyjnej w 2020 r. przeciętne wyniki egzaminów ósmoklasistów były, zwłaszcza w przypadku matematyki i języków obcych, zdecydowanie słabsze niż w większych miastach ${ }^{42}$.

Uwarunkowania decyzji edukacyjnych. Wyniki drugiej rundy badania panelowego gospodarstw domowych, red. I. Kotowska, A. Chłoń-Domińczak, Instytut Badań Edukacyjnych, Warszawa 2015.

42 Por. Centralna Komisja Egzaminacyjna, Osiągnięcia uczniów kończących VIII klasę szkoły podstawowej. Sprawozdanie za rok 2021. Matematyka, Warszawa 2021, s. 12. Uczniowie szkół wiejskich uzyskali na egzaminie z matematyki średnio 44\% pkt możliwych do zdobycia, uczniowie szkół w miastach do 20 tys. mieszkańców - 43\%, 
Szkoły w małych miejscowościach korzystają z pewnych preferencji finansowych przy podziale subwencji oświatowej. Preferencje te okazują się jednak niewystarczające, by szkołom tym zapewnić warunki umożliwiające ich uczniom osiąganie wyników nauczania porównywalnych z wynikami uczniów szkół w większych ośrodkach. Za konieczne należy uznać dokonanie takich zmian w systemie finansowania oświaty, które pozwoliłyby na zapewnienie równego dostępu do dobrej edukacji wszystkim uczniom, niezależnie od ich miejsca zamieszkania.

Poziom przypadających na jednego mieszkańca wydatków na administrację, zarówno w gminach wiejskich, jak i miejsko-wiejskich, jest tym większy, im mniejsza jest liczba mieszkańców gminy (tabela 6).

Tabela 6. Wydatki gmin (na jednego mieszkańca) na administrację według rodzajów gmin i klas liczby ludności

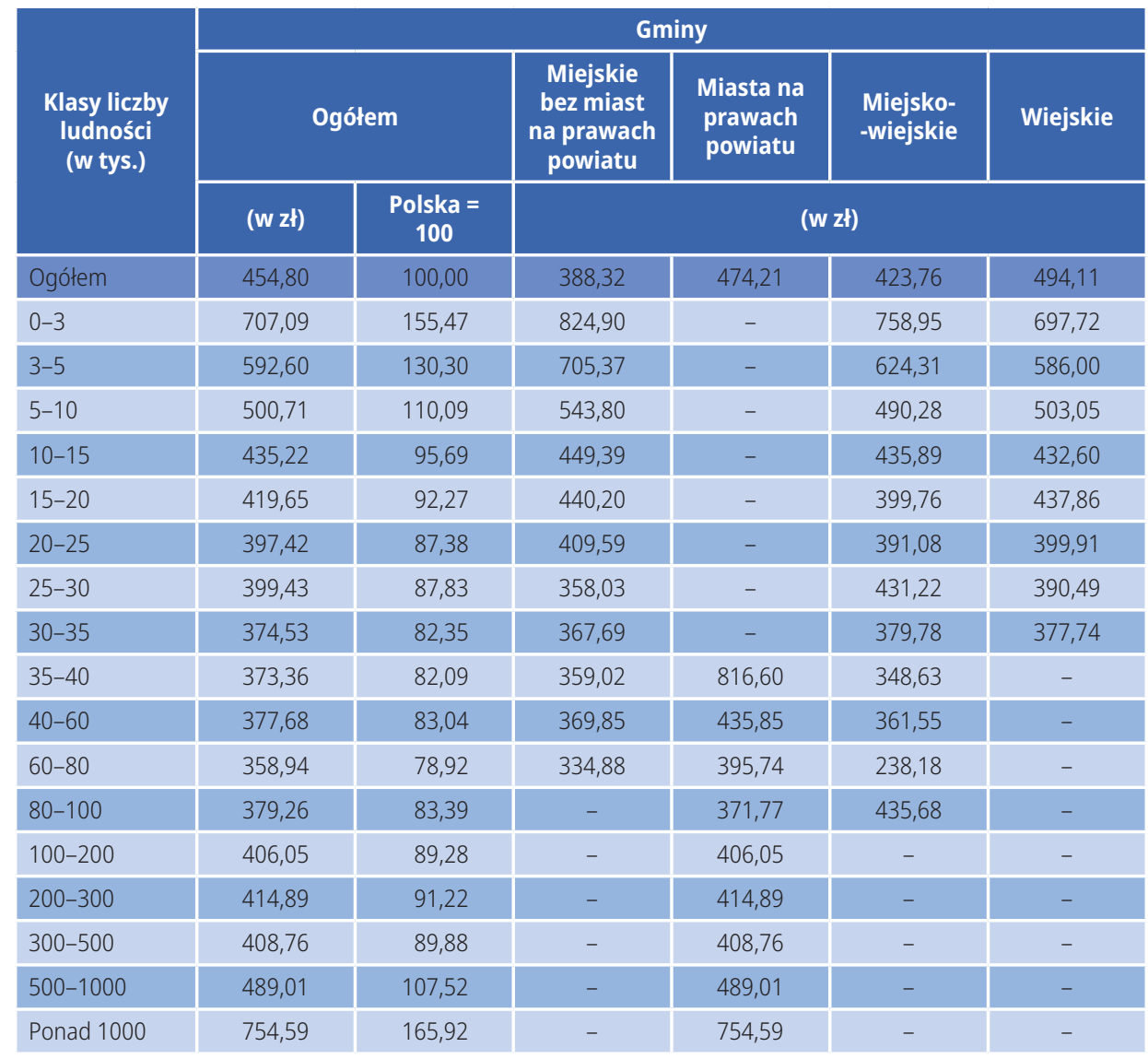

Źródło: obliczenia własne na podstawie danych Ministerstwa Finansów, https://www.gov.pl/web/finanse/bazy-danych3 [dostęp: 10 września 2021 r.].

a uczniowie ze szkół w miastach powyżej 100 tys. mieszkańców - 54\%. Jeszcze większe były różnice punktowe na egzaminie z języków obcych. Dane z 2021 r. nie odbiegają znacząco od wyników z poprzednich lat. 
Wysokie koszty administracji w małych gminach są spowodowane z jednej strony zróżnicowaniem zadań gmin wymuszającym zatrudnianie urzędników specjalizujących się w różnych dziedzinach działalności publicznej, z drugiej zaś - koniecznością dostosowania wynagrodzeń do sytuacji na rynku pracy, co w gminach o niskich dochodach może oznaczać ponoszenie wydatków nieadekwatnych do ograniczonych możliwości finansowych gminy.

Konsekwencją wysokich kosztów wykonywania zadań oświatowych i administracyjnych musi być ograniczenie wydatków na inne cele, szczególnie widoczne w danych o inwestycjach (por. tabela 7). Najmniejsze gminy, w większości których infrastruktura techniczna i społeczna wymaga znacznej poprawy, dysponują środkami na inwestycje niewspółmiernie małymi do ich potrzeb.

Tabela 7. Wydatki majątkowe gmin (na jednego mieszkańca) według rodzajów gmin i klas liczby ludności

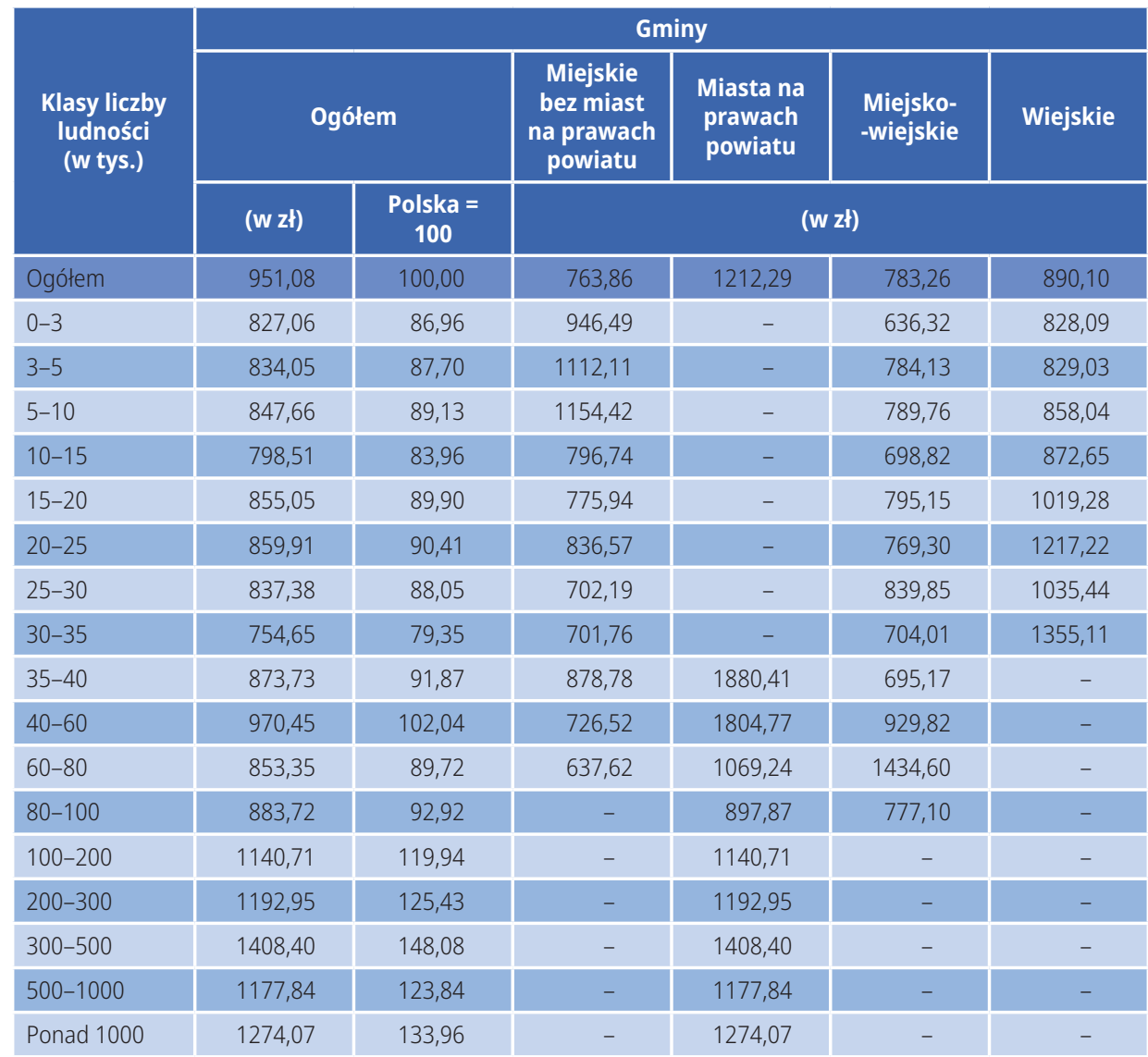

Źródło: obliczenia własne na podstawie danych Ministerstwa Finansów, https://www.gov.pl/web/finanse/bazy-danych3 [dostęp: 10 września 2021 r.]. 


\section{Wnioski}

Z bardzo skrótowej analizy zależności dochodów i wydatków gmin od ich wielkości wyznaczonej przez obowiązujący podział administracyjny i przez ustawowe regulacje kształtujące system finansów samorządowych można wysnuć następujące wnioski:

- Obecny podział administracyjny państwa charakteryzuje się daleko idącym rozdrobnieniem podstawowych jednostek samorządu terytorialnego i bardzo dużym zróżnicowaniem wielkości jednostek tego samego typu (szczebla).

- Najmniejsze gminy dysponują najmniejszymi - nie tylko w ujęciu bezwzględnym, lecz także w przeliczeniu na jednego mieszkańca - środkami na wykonywanie zadań samorządowych. Powinno to skłonić do ponownego rozważenia celowości samodzielnego funkcjonowania najmniejszych gmin i do dość istotnej redukcji ich liczby.

- Populacja gmin wiejskich jest mocno zróżnicowana wewnętrznie, przy czym najlepszą sytuacją finansową charakteryzują się gminy wiejskie, których podstawowe funkcje gospodarcze nie są związane z rolnictwem. Powinno to skłonić do ponownego rozważenia efektywności obecnego systemu wspierania rozwoju obszarów wiejskich.

- Konieczne wydają się korekty systemu finansów samorządowych, lepiej wiążące wielkość transferów środków z budżetu państwa do JST z uzasadnionymi kosztami wykonywania przez te jednostki zadań publicznych.

- Do pogłębienia analizy funkcjonowania obecnego podziału administracyjnego i systemu finansów samorządowych niezbędne jest rozszerzenie zakresu badań statystyki publicznej umożliwiające analizę jakości wykonywania przez wszystkie instytucje publiczne nałożonych na nie zadań.

- Nadal wymaga rozwiązania problem relacji dużych miast z otaczającymi je gminami. Zasadne wydaje się przy tym wdrożenie rozwiązań umożliwiających rozwój dużych ośrodków miejskich. Chociaż zbyt duża liczba małych gmin wydaje się głównym problemem obecnego podziału administracyjnego, należy zauważyć znaczące zróżnicowanie wielkości województw i powiatów. Ma ono źródło przede wszystkim w sposobie kształtowania siatki województw - bardziej ze względu na uwarunkowania polityczne niż zastosowanie jasnego zestawu kryteriów, które musiałyby być spełnione w przypadku obszarów tworzących województwa i miasta, wyznaczone na stolice tych województw.

\section{Bibliografia}

Blom-Hansen J., Houlberg K., Serritzlew S., Treisman D., Jurisdiction Size and Local Government Policy Expenditure: Assessing the Effect of Municipal Amalgamation „American Political Science Review” 2016, t. 110, nr 4, https:// doi.org/10.1017/s0003055416000320.

Bober J., Hausner J., Izdebski H., Lachiewicz W., Mazur S., Nelicki A., Nowotarski B., Puzyna W., Surówka K., Zachariasz I., Zawicki M., Narastajace dysfunkcje, zasadnicze dylematy, konieczne działania. Raport o stanie samorządności terytorialnej w Polsce, Małopolska Szkoła Administracji Publicznej Uniwersytetu Ekonomicznego w Krakowie, Kraków 2013. 
Centralna Komisja Egzaminacyjna, Osiagnięcia uczniów kończących VIII klasę szkoły podstawowej. Sprawozdanie za rok 2021. Matematyka, Warszawa 2021.

Consolidation or Fragmentation? The Size of Local Governments in Central and Eastern Europe, red. P. Swianiewicz, Local Government and Public Service Reform Initiative, Open Society Institute, Budapest 2002.

Edukacja małych dzieci. Standardy, bariery, szanse, red. A. Giza, Fundacja Rozwoju Dzieci im. Jana Amosa Komeńskiego, Polsko-Amerykańska Fundacja Wolności, Warszawa 2010.

Główny Urząd Statystyczny, Rocznik statystyczny 1974, Warszawa 1974.

Główny Urząd Statystyczny PRL, Rocznik statystyczny 1955, Warszawa 1956.

Główny Urząd Statystyczny Rzeczypospolitej Polskiej, Rocznik statystyczny 1950, Warszawa 1951.

Izdebski H., Reformy samorzqdu terytorialnego oraz centrum administracyjnego i gospodarczego rzadu po 1989 roku

[w:] Administracja państwowa i samorzad w Polsce w ujęciu historyczno-prawnym. Wybrane zagadnienia, red. E. Mreńca, P.B. Zientarski, B. Czwojdrak, Kancelaria Senatu, Warszawa 2018.

Izdebski H., Trzeci etap reformy samorzadu terytorialnego de(re)centralizacja, postcovid i...?. Analiza Celowa nr 4/2021, Centrum Ekspertyzy Lokalnej, Fundacja Rozwoju Demokracji Lokalnej im. Jerzego Regulskiego.

Mackiewicz M., Malinowska E., Misiąg W., Niedzielski A., Tomalak M., Public Finance in Poland 1989-2001. Case Study of Transformation, Instytut Badań nad Gospodarką Rynkową, Warszawa 2002.

Malinowska-Misiąg E., Potencjał dochodowy jednostek samorzq̨du terytorialnego w Polsce, Oficyna Wydawnicza SGH, Warszawa 2019.

Mazur S., Modernizacja samorządu lokalnego w wybranych krajach - ujęcie modelowe [w:] Sprawne państwo. Reformy samorzadu lokalnego w wybranych krajach, red. S. Mazur, Małopolska Szkoła Administracji Publicznej Uniwersytetu Ekonomicznego w Krakowie, Kraków 2015.

Mączyński M., Czy istnieje potrzeba reformowania i różnicowania podstaw ustrojowo-organizacyjnych lokalnego samorzadu terytorialnego w Polsce? Argumenty za i przeciw w świetle ustawy o samorzadzie powiatowym [w:] Sprawne państwo. Systemowe zmiany w funkcjonowaniu polskiego samorzqdu terytorialnego, red. M. Ćwiklicki, Małopolska Szkoła Administracji Publicznej Uniwersytetu Ekonomicznego w Krakowie, Kraków 2015.

Ministerstwo Administracji i Cyfryzacji, Ocena sytuacji samorzqdów lokalnych, Warszawa 2012.

Ministerstwo Administracji i Cyfryzacji, Polskie obwarzanki, Warszawa 2013 (prezentacja).

Ocena nowego zasadniczego podziału terytorialnego państwa przyjęta przez Radę Ministrów w dniu 12 grudnia 2000 r., przygotowana przez Ministerstwo Spraw Wewnętrznych i Administracji, Warszawa 2000.

Sekuła A., Ewolucja instytucji samorzqdu terytorialnego w Polsce po roku 1989 [w:] Samorzqd terytorialny w krajach Unii Europejskiej, red. K. Gomółka, Państwowa Wyższa Szkoła Zawodowa, Elbląg 2007.

Swianiewicz P., Ocena podziału terytorialnego państwa z uwzględnieniem efektywności funkcjonowania urzędów organów jednostek samorzqdu terytorialnego - wnioski i rekomendacje, Raport przygotowany na zlecenie Ministerstwa Administracji i Cyfryzacji, Warszawa 2014.

Swianiewicz P., Gendźwiłł A., Zardi A., Territorial Reforms in Europe: Does Size Matter? Territorial Amalgamation Toolkit, Centre of Expertise for Local Government Reform, Council of Europe, 2017.

Tavares A.F., Municipal Amalgamations and Their Effects: A Literature Review, "Miscellanea Geographica” 2018, t. 22, nr 1, https://doi.org/10.2478/mgrsd-2018-0005.

Territorial Consolidation Reforms in Europe, red. P. Swianiewicz, Local Government and Public Service Reform Initiative, Open Society Institute, Budapest 2010. 
Uwarunkowania decyzji edukacyjnych. Wyniki drugiej rundy badania panelowego gospodarstw domowych, red. I. Kotowska, A. Chłoń-Domińcza, Instytut Badań Edukacyjnych, Warszawa 2015.

Uwarunkowania decyzji edukacyjnych. Wyniki pierwszej rundy badania panelowego gospodarstw domowych, red. M. Rószczyńska, K. Saczek, Instytut Badań Edukacyjnych, Warszawa 2014.

\section{Akty prawne}

Konstytucja Rzeczypospolitej Polskiej z dnia 2 kwietnia 1997 r. (Dz.U. nr 78, poz. 483, ze zm.).

Rozporządzenie Rady Ministrów z dnia 15 grudnia 1998 r. w sprawie szczegółowych zasad prowadzenia, stosowania i udostępniania krajowego rejestru urzędowego podziału terytorialnego kraju oraz związanych z tym obowiązków organów administracji rządowej i jednostek samorządu terytorialnego (Dz.U. nr 157, poz. 1031, ze zm.).

Uchwała Rady Państwa i Rady Ministrów z dnia 24 lutego 1954 r. w sprawie prac przygotowawczych do powołania gromadzkich rad narodowych (M.P. $1954 \mathrm{nr} 22$, poz. 354).

Ustawa Konstytucyjna z dnia 17 października 1992 r. o wzajemnych stosunkach między władzą ustawodawczą i wykonawczą Rzeczypospolitej Polskiej oraz o samorządzie terytorialnym (Dz.U. nr 84, poz. 426, ze zm.).

Ustawa z dnia 20 marca 1950 r. o terenowych organach jednolitej władzy państwowej (Dz.U. nr 14, poz. 130).

Ustawa z dnia 25 września 1954 r. o reformie podziału administracyjnego wsi i powołaniu gromadzkich rad narodowych (Dz.U. nr 43, poz. 191).

Ustawa z dnia 29 listopada 1972 r. o utworzeniu gmin i zmianie ustawy o radach narodowych (Dz.U. nr 49, poz. 312).

Ustawa z dnia 28 maja 1975 r. o dwustopniowym podziale administracyjnym Państwa oraz o zmianie ustawy o radach narodowych (Dz.U. nr 16, poz. 91).

Ustawa z dnia 8 marca 1990 r. o samorządzie terytorialnym (Dz.U. nr 16, poz. 95).

Ustawa z dnia 17 maja 1990 r. o podziale zadań i kompetencji określonych w ustawach szczególnych pomiędzy organy gminy a organy administracji rządowej oraz o zmianie niektórych ustaw (Dz.U. nr 34, poz. 198).

Ustawa z dnia 5 czerwca 1998 r. o samorządzie powiatowym (Dz.U. 2020, poz. 920, ze zm.).

Ustawa z dnia 5 czerwca 1998 r. o samorządzie województwa (Dz.U. 2020, poz. 1668, ze zm.).

Ustawa z dnia 24 lipca 1998 r. o wprowadzeniu zasadniczego trójstopniowego podziału terytorialnego państwa (Dz.U. nr 96, poz. 603, ze zm.).

Ustawa z dnia 15 marca 2002 r. o ustroju miasta stołecznego Warszawy (Dz.U. 2018, poz. 1817).

Ustawa z dnia 13 listopada 2003 r. o dochodach jednostek samorządu terytorialnego (Dz.U. 2021, poz. 1672, ze zm.).

\section{Strony internetowe}

https://archiwum.mswia.gov.pl/pl/aktualnosci/1644,Zasadniczy-trojstopniowy-podzial-terytorialny-panstwa-jest-fundamentem-dla-racjo.html.

https://bdl.stat.gov.pl/BDL/.

https://eteryt.stat.gov.pl/eteryt/raporty/WebRaportZestawienie.aspx.

https://www.gov.pl/web/finanse/bazy-danych3. 